\title{
APAKAH SHISHA BERBAHAYA BAGI KESEHATAN RONGGA MULUT ?
}

\author{
Andi Anggun Mauliana Putri*, Gus Permana Subita ${ }^{* *}$
}

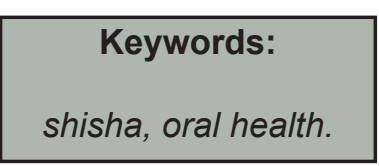

\begin{abstract}
Background: In recent years, the use of tobacco in Indonesia increasingly varied in the forms and methods of consumption, one of which is shisha. Smoking shisha is increasingly popular due to a misperception that smoking shisha is harmless and lack of knowledge about the effects of shisha smoking in oral health.
\end{abstract}

Literature analysis: "PubMed" used as a search tool to identify all empirical studies related to the effects of shisha smoking on health, especially in oral cavity.

Discussion: Shisha smoke contained various toxic substances such as Nicotine, Tobacco Specific Nitrosamines, Polycyclic Aromatic Hydrocarbons, Volatile Organic Compounds, Carbon Monoxide, Tar, and high-temperature metal heating causing shisha smoke contained toxic heavy metals such as arsenic, nickel, cobalt, chromium, lead, and cadmium. The content of these toxic substances showed that smoked shisha is associated with dependence, acute and long-term negative health effects similar to cigarette smoking. Toxic substances may cause various infections of microorganism such as Candida sp, Herpes Simplex Virus (HSV-1), Epstein Barr Virus, Mycobacterium tuberculosis, Human Immunodeficiency Virus; Oral mucosal changes such as Hairy Tongue, Smoker's Melanosis, Nicotine Stomatitis, Frictional Keratosis, Fissured Tongues, gingival or periodontal inflammation, and leukodema; and lead to malignant lesions such as Keratosis, Leukoplakia, Erythroplakia, Oral Submucous Fibrosis and Lichenoid Lesions.

Conclusion: Smoking shisha gives bad impact for human health especially oral health. Shisha smoking can lead to the development of various infectious diseases and potentially lead to malignancy in the oral mucosa. These foundings breaks the belief that shisha smoking is safe for health.

\section{PENDAHULUAN}

Penggunaan tembakau adalah penyebab kematian tertinggi kedua dan saat ini bertanggung jawab atas kematian satu dari sepuluh orang dewasa diseluruh dunia per tahun. Walaupun sudah dikonfirmasi melalui berbagai media bahwa merokok membahayakan kesehatan, namun jumlah perokok menunjukkan angka yang memprihatinkan. Jumlah konsusmsi rokok di Indonesia menempati posisi tertinggi di dunia yaitu sebesar 1,634 triliun batang. ${ }^{1}$
Dalam beberapa tahun terakhir semakin marak adanya rokok dari berbagai negara yang masuk ke Indonesia. Variasi rokok ini bukan hanya sebatas merek, namun juga bentuk dan cara mengonsumsinya. Saat ini sudah ada beberapa cara unik dalam menikmati rokok seperti yang telah dilakukan oleh sebagian penduduk di negara Timur Tengah. Cara ini dikenal dengan beberapa istilah seperti narghile, argile, hookah, waterpipe-smoke (WPS), goza, hubble-bubble, hubbly-bubbly, atau oleh masyarakat Indonesia sering disebut shisha. Shisha merupakan salah

${ }^{*}$ Resident of Oral Medicine Residency Program, Faculty of Dentistry, Universitas Indonesia , ${ }^{* *}$ Academic Staff of Oral Medicine Department, Faculty of Dentistry, Universitas Indonesia

Korespondensi: anggun.drg@gmail.com 
satu cara merokok dimana asap melewati air terlebih dahulu sebelum diinhalasi. Saat ini, penggunaan shisha dalam merokok tembakau berkontribusi pada peningkatan skala besar penggunaan tembakau diseluruh dunia, kebiasaan sejak 400 tahun yang lalu dan kini datang kembali. ${ }^{1,2,3}$

Merokok shisha menjadi populer karena kesalahpahaman masyarakat bahwa kandungan nicotine pada rokok shisha lebih rendah dibandingkan rokok sigaret dan air yang digunakan bekerja sebagai filter, menghilangkan seluruh bahan kimia berbahaya seperti $\mathrm{CO}$, nicotine dan tar. Selain itu terdapat beberapa mitos yang ada di masyarakat tentang merokok shisha antara lain shisha terdiri dari guci air yang dapat mengikat racun, lebih sedikit mengiritasi, sari buah yang ditambahkan pada shisha baik untuk kesehatan dan meninggalkan aroma yang menyenangkan. Kesalahpahaman ini menyebabkan masyarakat percaya bahwa merokok shisha tidak berbahaya bagi kesehatan mereka dan berkontribusi dalam peningkatan ledakan popularitas shisha. ${ }^{1,4,5}$

Sebagian besar bukti menunjukkan terdapat efek merugikan dari merokok siagaret terhadap kesehatan mulut, namun hanya sedikit penelitian yang menyebutkan efek merokok shisha terhadap kesehatan rongga mulut. Sebuah studi menemukan bahwa merokok shisha dikaitkan dengan peningkatan kehilangan tulang pada penyakit periodontal, peningkatan risiko dry socket setelah pencabutan gigi, serta faktor predisposisi bagi kanker mulut. Penelitian lainnya yang dilakukan oleh Monna Hassan dan Ahmed Hassan di Arab Saudi mengenai efek dari tembakau terhadap kesehatan rongga mulut dimana dari $100 \%$ sampel, terdapat $38,1 \%$ pengguna shisha dan hasilnya menyatakan bahwa ada dampak buruk terhadap mukosa mulut seperti keratosis, hairy tongue, smoker's melanosis, stomatitis nikotina, dan lainnya. ${ }^{3,6}$

Tinjauan literatur ini bertujuan untuk memberikan informasi terkait seberapa besar pengaruh buruk penggunaan rokok shisha bagi kesehatan rongga mulut yang diharapkan dapat berdampak pada penurunan prevalensi penggunaan rokok, khususnya shisha dan penyakit pada rongga mulut di Indonesia.

\section{DISKUSI}

Kata shisha berasal dari bahasa Persia yang memiliki arti gelas piala. Definisi shisha di beberapa negara berbeda satu dengan yang lainnya, masyarakat Arab lebih mengenalnya

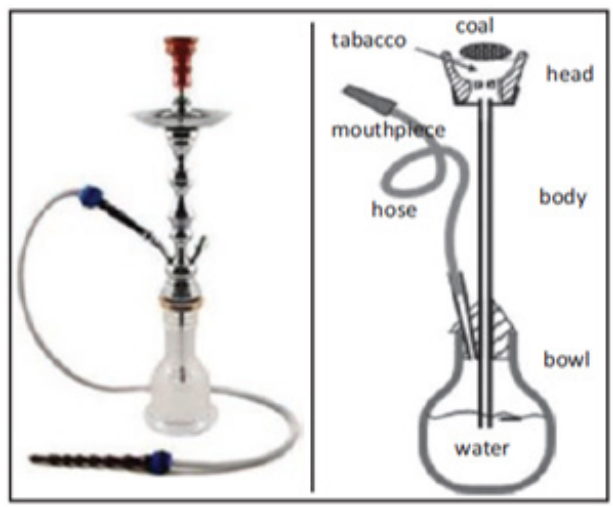

Gambar 1. Komponen utama rokok shisha ${ }^{5}$ 
dengan istilah "Hookah" atau "Hubble Bubble", bagi kalangan Pakistan dan India menyebutnya "huqqa", sedangkan di negaranegara Mediterania Arab dikenal dengan istilah "argile". ${ }^{2}$

Terdapat berbagai jenis alat pengisap shisha yang bervariasi dalam ukuran, bentuk, dan komposisi. Rokok shisha terdiri atas beberapa bagian utama, yakni mangkuk (bowl), selang (hose), badan tabung (body), katup (valve), dan tabung air (water jar). ${ }^{3}$

Merokok shisha melibatkan pembakaran tembakau menggunakan arang yang ditambahkan perasa, dikenal sebagai molase. Ketika seorang individu bernapas dari corong, udara ditarik melalui selang ke dalam tembakau dan dipanaskan oleh arang untuk menghasilkan asap. Hasilnya, asap mengandung komponen dari tembakau dan arang. Dalam hal ini termasuk Polycyclic Aromatic Hydrocarbons $(\mathrm{PAH})$, volatile aldehydes, Carbon Monoxide (CO), Nitric Oxide (NO), nicotine, furans, dan nanoparticles. Semua bentuk arang mengandung residu PAH kadar tinggi, terutama benzo(a)pyrene, sebuah karsinogen kuat. Paparan $\mathrm{PAH}$ yang signifikan mungkin menjadi penyebab dalam berkembangnya berbagai keganasan setelah merokok shisha. ${ }^{5}$

Volatile aldehydes juga ditemukan dalam asap shisha, termasuk formaldehyde, acetaldehyde, acrolein, propionaldehyde dan methacrolein. Bahan kimia ini berhubungan dengan berbagai gangguan pernapasan, iritasi saluran pernapasan, penyakit paru obstruktif kronik dan kanker paru-paru. Secara spesifik, formaldehyde dan acrolein merupakan karsinogen kuat yang dapat mendorong berkembangnya leukemia. ${ }^{5}$

Selain itu, tingkat COtelah diamati meningkat secara signifikan setelah merokok shisha.
Biasanya, konsentrasi carboxyhaemoglobin lebih dari $10 \%$ pada perokok shisha, dibandingkan dengan $6,5 \%$ pada perokok sigaret dan 1,6\% pada bukan perokok. Sebuah studi terbaru juga mencatat bahwa tingkat akut CO meningkat secara signifikan, mungkin berkontribusi terhadap keracunan CO. Dalam kasus ini, tingkat carboxyhemoglobin dapat mencapai $20-30 \%$ dan dapat menyebabkan hilangnya kesadaran, sakit kepala dan sesak napas. ${ }^{5}$

Kadar nicotine meningkat secara signifikan dari 2-6 $\mathrm{ng} / \mathrm{ml}$ setelah merokok shisha selama lima menit. Banyak perokok shisha mengacu pada penggunaan label tembakau shisha yang menunjukkan kadar "tar 0\%", "nicotine 0,05\%" atau "nicotine $0,5 \%$ ". Dalam suatu studi, diteliti tiga merek tembakau shisha, pada produk tembakau tersebut tertera kadar nicotine pada label kemasan sebesar 0,5\% (merek 1) atau 0,05\% nicotine (merek 2 dan 3). Konsentrasi nicotine plasma puncak terkait dengan produk tembakau ini adalah $9,8 \mathrm{ng} / \mathrm{ml}$ untuk Merek 1; $11,4 \mathrm{ng} / \mathrm{ml}$ untuk Merek 2, dan 5,8 ng/ml untuk Merek 3. Dengan kata lain, label produk tidak menunjukkan kadar prediktif nicotine yang sebenarnya. Label pada kemasan rokok shisha dapat menyebabkan perokok menjadi percaya bahwa rokok tersebut mengandung kadar zat beracun yang rendah atau bahkan tidak ada. ${ }^{4}$

"Tar" adalah komponen asap tembakau yang dihasilkan dari proses pembakaran. Namun, setelah tembakau dipanaskan dan menghasilkan asap, tar terbentuk dan terkandung dalam asap. Bahkan, asap dari penggunaan shisha memproduksi sekitar 802 mg tar, dibandingkan dengan 11,2 mg yang dihasilkan pada pembakaran satu batang rokok (memproduksi tar 71 kali lebih besar), fakta bahwa ada tar pada asap shisha tidak 
terbantahkan. ${ }^{7}$

\section{Perbandingan Zat Kimia Rokok Shisha dengan Rokok Sigaret}

Zat kimia yang dapat diidentifikasi dalam asap tembakau diketahui sebanyak 4800 jenis sedangkan 69 zat diantaranya adalah karsinogen (zat kimia yang diketahui menyebabkan kanker), dan beberapa lainnya merupakan pencetus tumor atau kokarsinogen. Zat tersebut secara luas dapat dibagi menjadi dua kelompok utama, yaitu bahan gas dan partikulat. ${ }^{8}$

Beberapa karsinogen yang dapat diidentifikasi di dalam rokok tembakau (termasuk shisha dan sigaret), antara lain :

\section{Nicotine}

Konsentrasi puncak dari nicotine pada rokok sigaret dan shisha adalah sama tetapi durasi panjang dari penggunaan shisha secara relatif menyebabkan paparan nicotine yang sangat besar. Pada sebuah studi menyebutkan bahwa kadar nicotine pada rokok sigaret sebesar 243 $\mathrm{ng} / \mathrm{ml} /$ menit sedangkan rokok shisha sebesar $418 \mathrm{ng} / \mathrm{ml} / \mathrm{menit}$. Dibandingkan rokok sigaret, perokok shisha dapat terpapar 1,7 kali dosis nicotine ketika mengisap tembakau melalui shisha. $^{2}$

Masyarakat percaya bahwa shisha mengandung sedikit nicotine karena air memiliki sifat penyaringan, dan beralih dari rokok sigaret ke rokok shisha akan mengurangi risiko kesehatan mereka. Akan tetapi, sebuah penelitian menunjukkan bahwa nicotine bersifat sangat larut dalam air, penetralan nicotine yang relatif rendah di dalam air kemungkinan disebabkan oleh nicotine di dalam air akan tersimpan di dalam gelembung udara dan sedikit waktu untuk terurai. Temuan ini kontras dengan kepercayaan beberapa perokok shisha bahwa air tersebut menghilangkan zat berbahaya. $^{9}$

2. Tobacco Specific Nitrosamines (TSNA)

Meskipun tidak stabil, kadar TSNAbiomarker nitrosamine, yakni 4-(methylnitrosamino)-1(3-pyridyl)-1-butanol (NNAL) mencerminkan paparan sistemik terhadap Nicotine-derived Nitrosamine Ketone (NNK) karsinogen paruparu, jauh lebih rendah saat merokok shisha dibandingkan dengan merokok sigaret. Tingkat NNAL urin dilaporkan lebih rendah pada perokok shisha dibandingkan dengan perokok sigaret. Hal ini mungkin disebabkan oleh perbedaan jenis tembakau atau proses pengawetan yang digunakan saat produksi atau mungkin karena zat pereduksi yang digunakan, seperti asam askorbat dalam persiapan buah yang menghambat pembentukan TSNA selama pengawetan atau penyimpanan. ${ }^{9}$

\section{Polycyclic Aromatic Hydrocarbons (PAH)}

Asupan naphthalene dan fluorene lebih tinggi saat merokok sigaret, namun asupan phenanthrene dan pyrene lebih tinggi selama merokok shisha. Hal tersebut menunjukkan $\mathrm{PAH}$ dengan berat molekul lebih tinggi tampak lebih banyak ditemukan pada asap shisha daripada sigaret. Karena $\mathrm{PAH}$ yang berat molekulnya lebih tinggi umumnya bersifat karsinogenik (misalnya benzo[a]pyrene dan benz[a]antrasena), kecenderungan ini menunjukkan bahwa risiko kanker yang disebabkan oleh PAH mungkin lebih tinggi pada perokok shisha daripada perokok sigaret. ${ }^{9}$

\section{Volatile Organic Compounds (VOCs)}

Paparan benzena merupakan karsinogen yang terbukti terkait dengan leukemia dan kanker paru-paru tampak jauh lebih tinggi saat merokok shisha dibandingkan sigaret. Hal ini mengejutkan mengingat tren untuk $\mathrm{PAH}$ 
dengan berat molekul tinggi lebih tinggi pada asap shisha. Mungkin arang yang terbakar adalah sumber utama benzena. Sebaliknya, asupan beberapa VOCs beracun lainnya seperti 1,3-butadiene, ethylene oxide, acrolein, acrylonitrile, dan propylene oxide lebih tinggi selama merokok sigaret. ${ }^{9}$

Pola yang berbeda dari paparan VOCs kemungkinan disebabkan oleh perbedaan komposisi produk dan perbedaan dalam proses merokok. Produk shisha sebagian besar merupakan campuran buah lembab yang mengandung sekitar $5-10 \%$ tembakau, tidak dibakar namun dipanaskan dengan menempatkan arang yang terbakar di atasnya. Dengan demikian suhu yang membentuk pyrolytic chemistry dan aerosol ditemukan sangat rendah dalam penggunaan shisha ( $\left.450^{\circ} \mathrm{C}\right)$ dibandingkan dengan sigaret $\left(\sim 900^{\circ}\right.$ C). ${ }^{9}$

\section{Carbon Monoxide (CO)}

Seperti dilaporkan dalam penelitian sebelumnya, asupan $\mathrm{CO}$ jauh lebih tinggi saat merokok shisha, mungkin karena arang pembakaran ditempatkan di atas campuran tembakau buah yang mengoksidasi zat dalam produk dan menghasilkan aerosol yang dapat dihirup. Carbon Monoxide mengurangi kadar oksigen darah dimana pada tingkatan yang tinggi sangat berbahaya pada orang dengan penyakit kardiovaskular iskemik dan paru obstruktif kronis, dimana paparan CO mengurangi kemampuan pergerakan tubuh dan meningkatkan risiko aritmia jantung yang berpotensi fatal. ${ }^{9}$

Volume gumpalan asap dari penggunaan shisha sekitar 10 kali lebih tinggi daripada sigaret. Pemanasan metal pada temperatur tinggi menyebabkan asap shisha mengandung sejumlah logam berat beracun yang signifikan lebih tinggi seperti arsenik, nikel, kobalt, kromium, timbal dan kadmium, dibandingkan dengan asap rokok sigaret. Fakta-fakta tentang asap shisha ini menjadi "peringatan keras" bahwa merokok shisha sangat berbahaya. ${ }^{1,2}$

\section{Efek Penggunaan Rokok Shisha terhadap Kesehatan Rongga Mulut}

Merokok shisha menjadi semakin terkenal, khususnya di kalangan anak muda dan dewasa muda. Bukti menunjukkan bahwa merokok shisha terkait dengan ketergantungan, efek kesehatan negatif akut dan jangka panjang yang serupa dengan merokok sigaret. ${ }^{1}$

Kebiasaan merokok shisha diketahui dapat memberikan berbagai efek negatif pada mulut, seperti staining pada gigi dan restorasi, menurunkan kemampuan penciuman dan pengecapan, salah satu faktor risiko penting terhadap kehilangan tulang periodontal, kemungkinan osteitis akut (dry socket) setelah pencabutan gigi, peningkatan kolonisasi spesies Candida dan karsinoma sel skuamosa. Penelitian lainnya melaporkan bahwa terdapat hubungan antara merokok shisha dengan keratoakanoma pada bibir, kanker nasofaring, kanker esofangeal, dan displasia oral. Namun hubungan tersebut tidak signifikan secara statistik. $5,7,10$

Merokok shisha berisiko tinggi terhadap terjadinya infeksi oleh Herpes Simpleks Virus (HSV-1), Epstein Barr Virus, Helicobacter pylori, Hepatitis B Virus; berbagai infeksi pernapasan, termasuk Meningitis bakteri, Mycobacterium tuberculosis; dan kolonisasi spesies Candida setelah merokok shisha. Seringkali, shisha digunakan secara bersama-sama dalam kelompok besar. Dengan berbagi pipa pengisap (mouthpiece), berbagai organisme komensal dan patogenik ditransmisikan melalui saliva, dapat berupa airborne maupun droplet. 
Patogen lainnya yang secara potensial dapat ditransmisikan termasuk Hepatitis C Virus dan Human Immunodeficiency Virus. 4,5,12

Belakangan ini, kafe shisha menyediakan pipa pengisap plastik sekali pakai untuk setiap konsumen, cara tersebut merupakan upaya untuk membatasi penyebaran penyakit. Risiko penyakit infeksi juga meningkat akibat kelembaban alami dari molase shisha, menciptakan lingkungan yang memicu pertumbuhan berbagai macam mikroorganisme. Terakhir, meskipun pipa pengisap shisha dicuci secara teratur, struktur kompenen alat pengisap shisha relatif kaku dan rumit sehingga hampir mustahil untuk membersihkan bagian dalam alat tersebut secara efektif. Misalnya, Mycobacterium tuberculosis dapat tumbuh dan bertahan pada permukaan internal pipa shisha dan air, secara signifikan meningkatkan risiko penularan penyakit. Di Timur Tengah, wabah penyakit menular telah berkorelasi dengan merokok shisha. Akl, dkk menggambarkan dua wabah pada tahun 2010 yang mengungkapkan kemungkinan hubungan antara Tuberkulosis (TB) dan penggunaan pipa shisha secara bersama-sama. ${ }^{5}$

Studi lain menilai hubungan antara merokok shisha dan lesi oral yang dicurigai kanker. Dalam sebuah studi cross sectional ditemukan bahwa tingkat lesi oral yang mencurigakan lebih besar ditemukan pada perokok shisha bahkan setelah disesuaikan dengan faktor perancu. Namun, hal tersebut tidak ditindaklanjuti oleh pasien sehingga diperlukan penelitian yang lebih komprehensif. ${ }^{11}$

\section{KESIMPULAN}

Berdasarkan berbagai penelitian terkait pengaruh penggunaan rokok shisha, sebagian besar menyimpulkan bahwa merokok shisha memberikan dampak buruk bagi kesehatan. Khususnya terkait kesehatan rongga mulut, kebiasaan mengisap sisha dapat menyebabkan perubahan pada rongga mulut dan meningkatkan risiko penularan penyakit infeksi mikroorganisme. Hal ini mematahkan kepercayaan yang berkembang di masyarakat selama ini bahwa merokok shisha aman bagi kesehatan.

Studi lebih lanjut diperlukan untuk mengklarifikasi dan menentukan patomekanisme merokok shisha dalam menimbulkan penyakit, khususnya di rongga mulut. Dari bukti yang ada dapat meningkatkan kesadaran masyarakat akan efek negatif potensial dari merokok shisha.

\section{ACKNOWLEDGEMENT}

Kami berterima kasih kepada dosen pembimbing dan seluruh pihak yang telah membantu dalam penyelesaian literatur ini.

\section{DAFTAR PUSTAKA}

1. Aslam HM, Saleem S, German S, Qureshi WA. Harmful effects of shisha : literature review. Int Arch Med. 2014;7(1):1-7.

2. Rasouli-ghahroudi AA, Derakhshan B, Khorsand A, Soleimani Y. Effect of hubble-bubble smoking on oral health. BEPLS. 2014;3(November):52-54.

3. Obeidat SR, Khabour OF, Alzoubi $\mathrm{KH}$, et al. Prevalence, social acceptance, and awareness of waterpipe smoking among dental university students: a cross sectional survey conducted in Jordan. BMC Res Notes. 2014;7(832):1-8.

4. Knishkowy B, Amitai Y. Water-pipe (narghile) smoking: an emerging health risk behavior. Pediatrics. 2005;116(1):e113-117.

5. Kadhum AM, Sweidan AA, Jaffery BAE, et al. A review of the health effects of smoking shisha. Clin Med (Northfield II). 2015;15(3):263-266.

6. Hassan M, Hassan A. Prevalence of potentially malignant oral mucosal lesions among tobacco users in Jeddah, Saudi Arabia. Asian Pac J Cancer Prev. 2014. Vol. 15:757.

7. Soule KE, Lipato T, Eissenberg T. Waterpipe tobacco smoking: A new smoking epidemic among the young?. Curr Pulmonal Rep. 2015;4(4):163-170.

8. Hashim R, Thomson WM, Pack AR. Smoking and 
periodontal diseases. Dental news. 2002; 9: 1-9.

9. Jacob $P$, Raddaha AHA, Dempsey $D$, et al. Comparison of nicotine and carcinogen exposure with water pipe and cigarette smoking. Cancer Epidemiol Biomarkers Prev. 2013; 22(5):765-772.

10. Dar-Odeh NS, Bakri FG, Al-Omiri MK, et al. Narghile (water pipe) smoking among university students in Jordan: prevalence, pattern and beliefs. Harm Reduction J. 2010, 7(10): 1-6.

11. Ali M, Jawad M. Health Effects of Waterpipe Tobacco Use: Getting the Public Health Message Just Right. Sage. 2016; 10: 1-8.

12. Martin R, Safaee SD, Somsamouth K, et al. Mixed methods pilot study of sharing behaviors among waterpipe smokers of rural Lao PDR: implications for infectious disease transmission. Int. J. Environ. Res. Public Health. 2013;10: 2120-2132. 